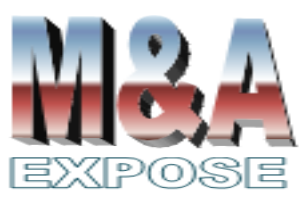

http://jurnal.usahid.ac.id/index .php/accounting
${ }^{1}$ Fakultas Ekonomi Universitas Serang Raya kodriyahunsera@gmail.com

${ }^{2}$ Fakultas Ekonomi

Universitas Serang Raya Vinamonica6496@gmail.com

\section{Perbandingan Asset Biologis Berdasarkan IAS 41 Agriculture dan PSAK 16 Aset Tetap}

\author{
Kodriyah $^{1}$, Vina Monica ${ }^{2}$
}

\section{Abstrak}

Tujuan dari penelitian ini adalah untuk menganalisis perbedaan perlakuan akuntansi aset biologis berdasarkan PSAK 16 dan IAS 41. Metode yang digunakan adalah pendekatan kualitatif. Populasi penelitian ini yaitu 16 perusahaan agrikultur dan mengambil 16 sampel perusahaan agrikultur yang terdaftar di BEI untuk tahun buku 2013-2017. Hasil penelitian menunjukan bahwa perlakuan akuntansi dalam hal pengakuan tidak berbeda, namun berbeda dalam hal pengukuran dan pengungkapan. Berdasarkan pengukurannya PSAK 16 mengakui aset dengan menggunakan biaya perolehan sedangkan IAS 41 menggunakan nilai wajar. PSAK 16 menyajikan dan mengungkapkan aset biologis dari pembibitan hingga pengolahan produk agrikultur pada titik panen menjadi produk jadi berikut penyusunannya, sedangkan IAS 41 hanya mengatur dan mengungkapkan aset biologis sampai pada titik panen saja dan tidak mengungkapkan penyusutan.

Kata Kunci : Perlakuan Akuntansi, Aset Biologis, PSA16, IAS 41

\section{Abstract}

The purpose of this study was to analyze differences in accounting treatment of biological assets based on PSAK 16 and IAS 41. The method used is a qualitative approach. The population of this study were 16 agricultural companies and took 16 samples of agricultural companies listed on the Stock Exchange for the 2013-2017 financial year. The results show that the accounting treatment in terms of recognition is not different, but different in terms of measurement and disclosure. Based on the measurement, PSAK 16 recognizes assets using cost, while IAS 41 uses fair value. PSAK 16 presents and reveals biological assets from nurseries to processing agricultural products at harvest points into finished products and their compilation, while IAS 41 only regulates and discloses biological assets to the point of harvest and does not disclose depreciation.

Keywords: Treatment Accounting, Biological Assets, PSAK 16, IAS 41 
Perbandingan Asset Biologis Berdasarkan IAS 41 ...

Kodriyah, Vina Monica

\section{PENDAHULUAN}

Indonesia merupakan Negara Agraris yang memiliki sumber daya alam yang sangat banyak. Dan sebagian penduduk Indonesia bermata pencaharian sebagai petani ataupun bekerja dibidang agrikultur. Pertanian Indonesia menghasilkan berbagai komoditi ekspor seperti padi, jagung, singkong, ubi, kedelai, sayur-sayuran, dan cabai. Selain itu Indonesia juga dikenal dengan hasil pekebunannya, seperti kelapa sawit, karet, kopi, teh, tembakau, dan kapas. Usaha agrikultur yang banyak dilakukan investor di Indonesia adalah usaha perkebunan, dengan banyaknya perusahaan perkebunan yang berada di Indonesia. Sebagian besar perusahaan di Indonesia bergerak di bidang pertanian maupun perkebunan, sehingga sebagian besar asetnya merupakan aset biologis.

Konvergensi International Financial Reporting Standard (IFRS) di Indonesia pada tahun 2012 menyebabkan perusahaan go public di Indonesia diwajibkan mengadopsi standar akuntansi keuangan internasional dan mengacu pada IFRS pada pembuatan laporan keuangan. Salah satunya adalah International Accounting Standard (IAS) 41 tentang Agriculture yang merupakan salah satu standar yang paling kontroversial mulai periode akuntansi 1 Januari 2003.

DSAK-IAI belum menerbitkan PSAK yang mengacu pada IAS 41 karena IAS 41 masih di revisi beberapa kali dari tahun ke tahun karena terdapat kesalahan dalam konsep nya. Sementara itu, perlakuan akuntansi aset biologis di Indonesia selama ini lebih mengacu pada Pernyataan Standar Akuntansi Keuangan (PSAK) 16 tentang aset tetap yang lebih menyinggung aset 'sebagai benda mati' dan bukan aset biologis 'sebagai benda hidup' yang mengalami transformasi biologis (Simanjorang, 2012). Hal ini dapat menimbulkan distorsi akuntansi yang dampaknya akan membuat Laporan Keuangan menjadi tidak andal dan relevan (Kurniawan, 2012:3). Bias yang terjadi pada pelaporan akuntansi, akan berdampak besar pada keakuratan pengambilan keputusan oleh pengguna laporan keuangan.

Ada dua hal yang kontroversial yang dituntut dari IAS 41. Pertama mengenai Bareer Biological Asset (BBA) yang disarankan untuk tidak dimasukan ke dalam lingkup IAS 41, melainkan IAS 16 tentang Property, Plant, and Equipment (IAS 16 sama dengan PSAK 16 Aset Tetap), karena BBA tidak untuk dijual, sehingga tidak perlu untuk mengakuinya berdasarkan fair value. Maka, tidak relevan juga mengakui gain/lose perubahan nilai wajar dari BBA. Kedua, sebaiknya hanya Consumable Biological Asset (CBA) saja yang tetap dalam lingkup IAS 41. Perlakuan akuntansi untuk BBA seharusnya seperti yang diatur dalam PSAK 16. Sedangkan untuk CBA, tidak berlaku mengalami kontroversi, terkecuali untuk menemukan nilai wajar dari beberapa asset biologis ada tempat-tempat tertentu, sehingga teteap menggunakan IAS 41 pun tidak menjadi masalah.

Berdasarkan PSAK 16, aset biologis dapat diukur menggunakan biaya historis. Biaya historis didasarkan pada harga perolehan awal dari aset tersebut. Namun sayangnya, metode biaya historis dianggap kurang mampu menyampaikan informasi yang wajar terkait nilai aset terkini. Selain itu, menggunakan biaya historis dinyatakan kurang relevan dan andal. Sebaliknya, metode nilai wajar memungkinan bagi setiap entitas untuk merevaluasi aset biologisnya pada setiap periode. Metode ini muncul karena pemikiran bahwa aset biologis tumbuh dan dapat mengalami perubahan nilai setiap waktu, yang biasa dikenal dengan transformasi biologis. Sayangnya, metode ini juga memiliki kelemahan, selain memakan biaya yang cukup tinggi dalam aplikasinya, terkadang untuk beberapa aset biologis nilainya tidak tersedia di pasar, sehingga sulit untuk menentukan nilainya. 
International Accounting Standard (IAS) 41 Agriculture muncul untuk menjawab keberagaman yang terjadi dalam pengungkapan aset biologis untuk memenuhi kebutuhan informasi akuntansi global. IAS 41 memperkenalkan metode fair value sebagai dasar pengukuran aset biologis. Hingga saat ini IAS 41 masih mengandung perdebatan berkaitan dengan penerapan metode nilai wajar dalam IAS 41. Agrikultur sebagai metode pengakuan dan pengukuran asset biologis di Indonesia menggunakan metode harga perolehan dikurangi akumulasi penyusutan. Sampai saat ini aset biologis merupakan aset yang tidak dikecualikan dari PSAK 16 Aset Tetap. Namun hal tersebut menimbulkan permasalahan mengingat tidak semua aset biologis mengalami penyusutan.

Terdapat sebelas perusahaan perkebunan yang terdaftar di Bursa Efek Indonesia, hanya PT. Sampoerna Agro Tbk yang dianggap sudah mulai melakukan perubahan menuju ke arah penerapan IAS 41 Agriculture (Amanah, 2012). Hal ini terbukti dalam pernyataan manajemen yang menyebutkan bahwa dalam menentukan harga pasar crude palm oil perusahaan menggunakan harga spot. Menurut penelitian Adita Kiswara (2012 : 10) ada perubahan signifikan setelah PT. Sampoerna Agro, Tbk menerapkan IAS 41 agrikultur yaitu salah satunya pada penilaian aset biologis. Sebelum penerapan IAS 41, perusahaan masih mengakui adanya akumulasi depresiasi pada aset biologis. Sedangkan setelah penerapan IAS 41, perusahaan tidak lagi mengakui adanya akumulasi depresiasi. Aset biologis diukur berdasarkan nilai wajarmya. Dengan begitu laporan keuangan perusahaan dapat di anggap reliability. Hal tersebut dapat dijadikan acuan oleh perusahaan agrikultur lainnya di Indonesia bahwa perlu nya menerapkan IAS 41 Agrikultur. Sehubungan dengan hal tersebut, penulis tertarik untuk melakukan penelitian mengenai Perbandingan Asset Biologis Berdasarkan IAS 41 Agriculture dan PSAK 16 Aset Tetap.

\section{TINJAUAN PUSTAKA}

Aset Biologis. Aset biologis merupakan jenis aset berupa hewan dan tumbuhan hidup, seperti yang didefinisikan dalam IAS 41 : "Biological asset is a living animal or plant". Jika dikaitkan dengan karakteristik yang dimiliki oleh aset maka Aset Biologis dapat dijabarkan sebagai tanaman pertanian atau hewan ternak yang dimiliki oleh perusahaan yang diperoleh dari kegiatan masa lalu. Aset Biologis merupakan aset yang sebagian besar digunakan dalam aktivitas agrikultur, karena aktivitas agrikultur adalah aktivitas usaha dalam rangka manajemen transformasi biologis dari Aset Biologis untuk menghasilkan produk yang siap dikonsumsikan atau yang masih membutuhkan proses lebih lanjut.

Karakteristik khusus yang membedakan asset biologis dengan aset lainnya yaitu bahwa asset biologis mengalami transformasi biologis. Tranformasi biologis merupakan proses pertumbuhan, degenerasi, produksi, dan prokreasi yang disebabkan perubahan kualitatif dan kuantitatif pada makhluk hidup dan menghasilkan aset baru dalam bentuk produk agrikultur atau aset biologis tambahan pada jenis yang sama (Kurniawati, 2012).

Bearer Biological Asset (BBA) dan Consumable Biological Asset (CBA). IAS 41 mengklasifikasikan asset biologis menjadi dau jenis, yaitu consumable biological asset (CBA) dan bearer biological asset (BBA). CBA didefinisikan sebagai asset biologis yang akan dipanen sebagai produk agrikultur atau yang akan dijual sebagai asset biologis. Selain dari sifat-sifat yang dimiliki oleh CBA, maka akan diklasifikasikan ke dalam BBA. BBA tidak 
untuk dipanen sebagai produk agrikultur ataupun dijual sebagai asset biologis, lebih condong pada self-regenerating.

Aset Tetap. Menurut PSAK No. 16 Paragraf 5, aset tetap adalah aktiva berwujud yang diperoleh dalam bentuk siap pakai atau dengan dibangun lebih dahulu, yang digunakan dalam operasi perusahaan, tidak dimaksudkan untuk dijual dalam rangka kegiatan normal perusahaan dan mempunyai masa manfaat lebih dari satu tahun.

Pasar Aktif. Dalam menentukan nilai wajar dari suatu asset biologis atau produk agrikultur, IAS 41 dalam paragraf 8 mengenal istilah pasar aktif (active market) yang didefinisikan sebagai sebuah pasar yang memenuhi kondisi-kondisi di bawah ini, yaitu:

a. Barang-barang diperdagangkan dalam pasar tersebut bersifat homogeny.

b. Pembeli dan penjual yang ingin bertransaksi dapat ditemukan kapan saja.

c. Harga-harga tersedia bagi publik.

Apabila ada pasar yang memenuhi semua kondisi di atas, maka harga dari pasar tersebut terhadap asset biologis atau produk agrikultur pada kondisi dan lokasi saat ini, dapat menjadi acuan dalam menentukan nilai wajar. Apabila perusahaan menemukan pasar aktif yang lain, maka perusahaan harus menentukan salah satu pasar yang paling relevan untuk digunakan sebagai acuan.

Namun, apabila pasar aktif tidak dapat ditemukan oleh perusahaan, IAS 41 paragraf 18 mensyaratkan acuan lain yang bisa digunakan sebagai alternatif dalam menentukan nilai wajar produk atau aset, yaitu :

a. Harga transaksi pasar terkini, yang disyaratkan dengan tidak adanya perubahan keadaan ekonomi yang signifikan antara tanggal transaksi dan masa akhir dari periode pelaporan

b. Harga pasar untuk asset yang mirip, dengan penyesuian untuk mencerninkan perbedaan

c. Benchmark terhadap sektor, seperti nilai dari sebuah kebun buah yang dinyatakan per hektar, atau seekor sapi yang dinyatakan per kilogram daging (Kiswara, 2012:9).

Kemudian dinyatakan dalam IAS 41 paragraf 19, apabila dari alternatif-alternatif tersebut menghasilkan suatu kesimpulan akhir mengenai estimasi nilai wajar yang paling andal diantara beberapa pilihan dari estimasi yang layak.

\section{METODE PENELITIAN}

Penelitian ini bersifat deskriptif kualitatif komparatif dengan tujuan untuk memberikan gambaran awal mengenai pengakuan, pengukuran, penyajian dan pengungkapan asset biologis berdasarkan IAS 41 dengan PSAK 16. Kemudian menganalisis perbedaan dalam akuntansi untuk asset biologis berdasarkan IAS 41 dengan PSAK 16. Metode analisis data yang digunakan oleh peneliti adalah dengan menggunakan Deskriptif Kualitatif Komparatif. Tujuan dari penelitian ini adalah mengungkap fakta, keadaan, fenomena, variabel dan keadaan yang terjadi saat penelitian berjalan dan menyuguhkan apa adanya. Kegiatan penelitian ini meliputi pengumpulan data, menganalisis data, meginterprestasi data, dan diakhiri dengan sebuah kesimpulan yang mengacu pada penganalisisan data tersebut. 


\section{HASIL DAN PEMBAHASAN}

Pengakuan Aset Biologis Berdasarkan IAS 41. Berdasarkan yang saya tulis di latar belakang bahwa PT. Sampoerna Agro Tbk. merupakan salah satu perusahaan yang dianggap sudah mulai melakukan perubahan menuju ke arah penerapan IAS 41 Agrikuktur. Sebelum menerapkan IAS 41 dalam pengakuannya PT. Sampoerna Agro Tbk. mengakui adanya amortisasi pada tanaman perkebunannya yaitu pada tanaman menghasilkan. Namun setelah penerapan IAS 41 pengakuan tanaman menghasilkan dan tanaman belum menghasilkan tidak terdapat akumulasi amortisasi.

Pengakuan aset biologis yang dicatat dalam perusahaan adalah aset tanaman belum menghasilkan (TBM) dan tanaman menghasilkan (TM). Tanah yang terkait dengan aktivitas agrikultur tentang properti, pabrik, dan peralatan atau terhadap aset tidak berwujud yang berhubungan dengan akuntansi agrikultur tidak diatur dalam IAS 41.

Pengukuran Aset Biologis Berdasarkan IAS 41. Di dalam IAS 41 pengukuran aset biologis diukur sesuai dengan nilai wajar dikurangi biaya penjualan, kecuali jika nilai wajar tidak dapat diukur secara reliable dalam konidisi lain nilai historis dapat digunakan. Yang menjadi dasar penentuan nilai wajar adalah nilai pasar, hanya jika elemen keuangan memiliki pasar aktif, dan pasar aktif ini juga menjadi pedoman untuk menilai keadaan aset yang sebenarnya, tempat aset, kondisi, yang sesuai pada tanggal neraca. Akan tetapi jika untuk hal-hal khusus tidak layak atau sulit dilakukan penilaian wajar maka dibolehkan menilai dengan historical cost. Berikut merupakan cara menentukan nilai wajar pada PT. Sampoerna Agro Tbk. :

1. Harga pasar transaksi terbaru, asalkan belum ada perubahan signifikan dalam keadaan ekonomi antara tanggal transaksi dan periode akhir pelaporan;

2. Harga pasar untuk aset serupa dengan penyesuaian

3. Benchmark, seperti nilai kebun yang dinyatakan perhektar, dan nilai ternak yang dinyatakan per kilogram daging.

Nilai wajar yang digunakan oleh PT. Sampoerna Agro, Tbk adalah harga spot, yaitu harga yang berlaku saat terjadinya transaksi. Jika ada kontrak harga tetap akibatnya, nilai wajar dari aset biologis atau hasil agrikultur tidak disesuaikan karena adanya kontrak.

Pengungkapan dan Penyajian Aset Biologis Berdasarkan IAS 41 Agriculture. Salah satu perusahaan yang sudah menerapkan IAS 41 dalam pengungkapannya yaitu PT. Sampoerna Agro Tbk. Pencatatan aset biologis menurut IAS 41 tidak mengakui adanya depresiasi, maka pada laporan laba/rugi tidak ada akumulasi depresiasi yang berakibat adanya kenaikan pada laporan laba/rugi. Kemudian laporan arus kas pada PT. Sampoerna Agro Tbk. tidak menjelaskan mengenai konsep laporan arus kas secara jelas, hanya saja pada IAS 41 ini menggunakan metode fair value yaitu nilai yang saat ini sedang berlaku sehingga akan lebih relevan, untuk metode yang digunakan tidak ada ketentuan secara pasti.

Pengakuan dan Pengukuran Aset Biologis Berdasarkan PSAK 16 Model Biaya. Sampai dengan saat ini nilai tercatat aset biologis perusahaan agrikultur di Indonesia diakui dan diukur berdasarkan biaya perolehan (model biaya) sesuai dengan ketentuan dalam paragraf 30 PSAK 16 Aset Tetap (revisi 2015). Ketentuan akuntansi tentang model biaya ini tidak berbeda antara PSAK 16 lama dengan (PSAK 16 Revisi 2015). Salah satu perusahaan agrikultur di Indonesia bergerak di bidang tanaman kelapa sawit yaitu pada PT. Salim Ivomas Pratama Tbk. Tanaman kelapa sawit memerlukan waktu sekitar 3 sampai dengan 4 
tahun sejak penanaman bibit di area perkebunan. Pengukuran biaya perolehan tanaman kelapa sawit terdiri dari kapitalisasi biaya-biaya untuk persiapan pembibitan, pembelian kecambah dan pemeliharaan. Biaya-biaya yang terjadi setelah menjadi Tanaman Menghasilkan dibebankan sebagai beban di tahun berjalan.

Biaya perolehan tanaman perkebunan menghasilkan amortisasi dengan menggunakan metode garis lurus berdasarkan taksiran masa manfaat ekonomisnya. Manajemen mengestimasi masa manfaat ekonomis tanaman perkebunan, yang terutama terdiri atas tanaman kelapa sawit dan karet, adalah selama 25 tahun, yang merupakan umur secara umum diharapkan dalam industri perkebunan.

Tabel 1 berikut menunjukan pengungkapan nilai tercatat tanaman perkebunan TM dan TBM berdasarkan PSAK 16 Model Biaya pada perusahaan agrikultur tahun 2017 :

Tabel 1

Komposisi Tanaman Menghasilkan dan Tanaman Belum Menghasilkan

\begin{tabular}{crrrrr}
\hline Dalam Jutaan Rupiah & \multicolumn{1}{c}{ PT. AALI } & PT. ANJT & \multicolumn{1}{c}{ PT. BWPT } & PT. DSNG & PT. SIMP \\
\hline TM & & & & & \\
1. Biaya Perolehan & 7.181 .531 & 212.221 & 9.654 .763 & 2.421 .725 & 9.875 .804 \\
2.Akumulasi Depresiasi & $(2.026 .754)$ & $(109.334)$ & $(2.065 .203)$ & $(599.090)$ & $(3.500 .482)$ \\
Nilai Buku TM dan & 5.154 .777 & 102.877 & 8.845 .718 & 1.822 .635 & 6.375 .332 \\
TBM & 1.592 .437 & 100.016 & 1.173 .793 & 945.225 & 3.028 .276 \\
Total Nilai Buku Tanaman & 6.747 .214 & 202.893 & 10.019 .511 & 2.767 .860 & 9.403 .608 \\
$\quad$ Perkebunan & & &
\end{tabular}

Sumber: diolah dari laporan keuangan perusahaan agrikultur tahun 2017

PT. Provident Agro, Tbk tidak mengungkapkan pengukuran aset biologis menggunakan metode biaya karena perusahaan dan entitas anaknya melakukan perubahan kebijakan akuntansi atas aset tetap tanah dan tanaman dari model biaya menjadi model revaluasi sejak tanggal 1 Januari 2012.

Pengungkapan dan Penyajian Aset Biologis Berdasarkan PSAK 16. Berdasarkan pengukuran PT. Astra Agro Lestari Tbk yang masih menggunakan PSAK 16 yaitu mengakui aset dengan menggunakan biaya perolehan. PSAK 16 menyajikan dan mengungkapkan aset biologis dari pembibitan hingga pengolahan produk agrikultur pada titik panen menjadi produk jadi berikut penyusutannya.

Tabel 2

Perbandingan IAS 41 dan PSAK 16

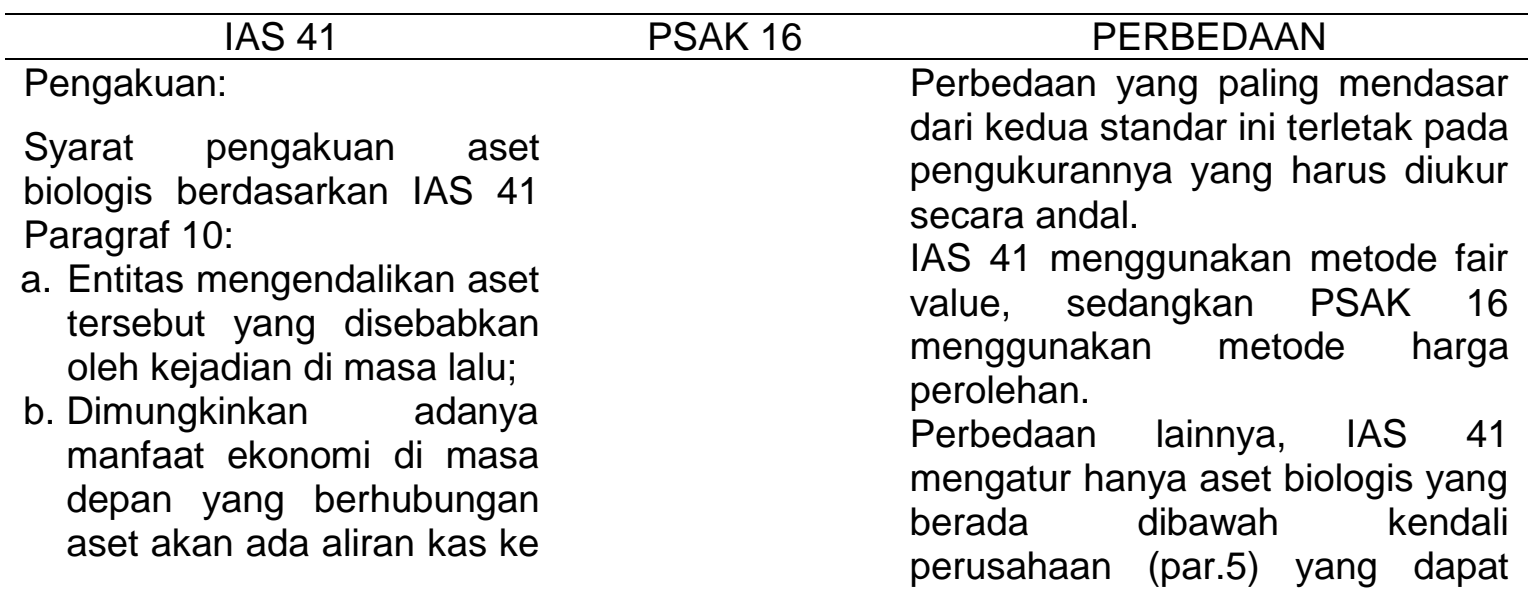


entitas tersebut;

c. Nilai wajar atau harga perolehan dari aset bisa di ukur secara andal.

Pengukuran

IAS 41 menggunakan fair value (nilai wajar) dalam pengukurannya. Nilai wajar dari aset biologis dan produk agrikultur di ukur pada keadaan pasar aktif.

Penyajian \& pengungkapan:

Berdasarkan penyajian \& pengungkapannya IAS 41 mengungkapkan aset biologis sampai pada titik panen saja tidak mengungkapkan penyusutannya.
Pengukuran

Suatu aset tetap yang memenuhi kualifikasi untuk diakui sebagai aset pada awalnya harus diukur sebesar biaya perolehan.

Penyajian \& pengungkapan:

PSAK 16 menyajikan\&men gungkapkan aset biologis dari pembibitan hingga pengolahan produk agrikultur pada titik panen menjadi produk jadi berikut penyusutannya.
diakui sebagai aset biologis.
Sedangkan pemanen dari sumber yang bukan hasil pengelolaan perusahaan bukanlah kegiatan agrikultur sehingga hasil pemanenan tidak bisa diakui sebagai aset biologis (par.6b)

Karena menggunakan metode fair value, maka IAS 41 mewajibkan untuk melakukan pengukuran pada saat pengakuan awal dan setiap akhir periode berdasarkan nilai wajar yang dikurangi dengan estimasi biaya penjualan.

PSAK 16 mengatur bahwa aset pada awalnya harus diakui berdasarkan biaya perolehannya

IAS 41 yang dikhususkan untuk sektor agrikultur, mempunyai kelebihan dalam kompleksitas pengungkapan yang diwajibkan untuk aset biologis. Banyak istilah juga yang lebih dapat dipahami atau digunakan dalam sektor usaha agrikultur sehingga akan lebih memudahkan daripada menggunakan PSAK 16 yang dikeluarkan oleh IASB untuk aset tetap yang merupakan benda mati.

\section{KESIMPULAN}

1. Syarat pengakuan aset biologis berdasarkan IAS 41 yaitu Entitas mengendalikan aset tersebut yang disebabkan oleh kejadian di masa lalu dan aset dapat diukur secara andal menggunakan nilai wajar (fair value). Pengukuran aset biologis berdasarkan IAS 41 menggunakan metode nilai wajar yang diukur pada keadaan pasar aktif. Berdasarkan penyajiannya IAS 41 mengungkapkan aset biologis sampai pada titik panen saja tidak mengungkapkan penyusutannya.

2. Pengakuan pada suatu aset tetap yang diatur oleh PSAK 16 yang memenuhi kualifikasi untuk diakui sebagai aset pada awalnya harus diukur sebesar biaya perolehan. Berdasarkan pengukurannya PSAK 16 mengakui aset dengan menggunakan biaya perolehan. PSAK 16 menyajikan dan mengungkapkan aset biologis dari pembibitan hingga pengolahan produk agrikultur pada titik panen menjadi produk jadi berikut penyusutannya. 
3. Perlakuan akuntansi dalam hal pengakuan aset biologis Tidak terdapat perbedaan yang signifikan antara IAS 41 dan PSAK 16. Perbedaannya hanya terletak pada pengendalian asetnya saja (kejadian masa lalu). Aset menurut IAS 41 dapat dijual (CBA) sedangkan aset menurut PSAK 16 (BBA) tidak dapat dijual.

4. Adopsi IAS 41 menjadi standar akuntansi keuangan agrikultur di Indonesia berpotensi masalah karena pengukuran nilai wajarnya berbeda signifikan dibandingkan dengan pengukuran berbasis biaya perolehan (metode biaya) yang selama ini digunakan dalam PSAK 16. Dari 16 sampel perusahaan perkebunan dan pertanian sebanyak 15 perusahaan masih menggunakan metode biaya dalam hal pengukurannya. Hal tersebut dianggap menimbulkan distorsi akuntansi (Laporan keuangan yang tidak relevan).

5. Penyajian laporan posisi keuangan antara IAS 41 .dan PSAK 16 berbeda signifikan karena pencatatan aset biologis menurut IAS 41 tidak mengakui adanya akumulasi depresiasi sedangkan pencatatan aset biologis menurut PSAK 16 mengakui adanya akumulasi depresiasi. Hal tersebut dapat mengakibatkan perbedaan nilai pada laporan laba/rugi.

\section{SARAN}

1. Untuk Perusahaan

a. Perusahaan perkebunan dan pertanian di Indonesia hendaknya untuk memahami IAS 41 sehingga dapat mengidentifikasikan masalah-masalah yang mungkin timbul pada saat penerapannya. Hal ini mencakup penyamaan persepsi dengan DSAK-IAI dan regulator tentang perlakuan akuntansi dan dampaknya terhadap laporan keuangan.

b. Dengan diterbitkannya PSAK 69 agrikultur yang telah diadopsi dari IAS 41 agrikiltur. 15 perusahaan yang masih menggunakan PSAK 16 pada perlakuan akuntansinya diharapkan segera menerapkan PSAK 69 Agrikultur dalam pembuatan laporan keuangan. Untuk meminimalisir laporan keuangan yang tidak relevan sehingga para investor dapat mengambil keputusan yang rasional.

2. Untuk Peneliti Selanjutnya

a. Bagi peneliti yang akan mengambil tema yang sama, sebaiknya lebih memfokuskan kepada praktik akuntansi aset biologis di satu perusahaan saja sehingga bisa diketahui pencatatan akuntansi yang tepat untuk aset biologis.

b. Acuan penelitian sebelumnya mayoritas berasal dari dalam Indonesia yang negaranya belum menerapkan IAS 41. Penelitian tentang aset biologis berdasarkan PSAK 16 dan IAS 41 di Indonesia belum banyak dilakukan. Pada peneliti selanjutnya sebaiknya lebih banyak beracuan pada penelitian yang dilakukan dari luar Indonesia yang negaranya sudah menerapkan IAS 41 sehingga bisa melihat permasalahan yang lebih aktual yang terjadi secara global.

3. Untuk Regulator Akuntansi

a. Bagi IASB (International Accounting Standard Board) disarankan untuk melakukan revisi terhadap IAS 41 terkait dengan standar akuntansinya. Di dalam IAS 41 sebaiknya dipisahkan antara CBA dan BBA. IAS 41 sebaiknya hanya mengatur perilaku akuntansi untuk CBA (Consumable Biological asset) sedangkan untuk BBA (Bearer Biological Asset) sebaiknya masuk dalam IAS yang mengatur tentang aset tetap. 
b. Bagi IAI, disarankan untuk tetap melakukan adopsi IAS 41 namun dengan beberapa pengecualian. IAS 41 meskipun masih mengalami kontroversi, namun merupakan satu-satunya standar yang relevan bagi CBA, yang mana pada saat ini belum ada di Indonesia dan juga tidak tepat jika menggunakan PSAK 16.

\section{DAFTAR PUSTAKA}

Adita, K. 2012. Analisis Penerapan International Accounting Standard (IAS) 41 Pada PT . Sampoerna Agro, Tbk. Diponegoro Journal of Accounting. Vol. 1, pp. 1-14. Diakses dari https://doi.org/10.1587/transfun.E94.A.2306

Dian Martha Nurrul Amanah, F. R. 2007. Analisis Perbandingan Perlakuan Akuntansi Aset Biologis Pada Industri Perkebunan.

Elad, C. 2007. Fair value accounting and fair trade: An analysis of the role of international accounting standard No. 41 in social conflict. Socio-Economic Review. Vol. 5 No.4, pp. 755-777. Diakses dari https://doi.org/10.1093/ser/mwm013.

Farida, I. dan Surabaya, U.N. 1979. Analisis Perlakuan Akuntansi Aset Biologis Berdasarkan International Accounting Standard 41 Pada PT. Perkebunan Nusantara VII (Persero), pp. 1-24.

Kurniawan, R. Mulawarman, A.D. dan Kamayanti, A. 2014. Biological Assets Valuation Reconstruction: A Critical Study of IAS 41 on Agricultural Accounting in Indonesian Farmers. Procedia - Social and Behavioral Sciences. Vol. 164, pp. 68-75. Diakses dari https://doi.org/10.1016/j.sbspro.2014.11.052

Kurniawati, H. 2013. Tinjauan Rencana Adopsi IAS 41 Pada Perusahaan Agrikultur Di Bursa Efek Indonesia. Nasional. Vol.4 No.9, pp. 462-472. Diakses dari https://doi.org/10.1128/mBio.01653-16.

Maruli, S. dan Mita, F. 2010. Analisis Pendekatan Nilai Wajar dan Nilai Historis Dalam Penilaian Aset Biologis Pada Perusahaan Agrikultur: Tinjauan Kritis Rencana Adopsi IAS 41. Simposium Nasional Akuntansi XIII Purwokero 2010, pp. 1-38. Diakses dari https://doi.org/10.1109/ICMTMA.2009.665

Putra, A.V.W. Pangemanan, S.S. dan Wokas, H.R.N. 2017. Analisis Perbandingan perlakuan Akuntansi Terhadap Aset Biologis dan Non Biologis. Vol. 3 No. 1, pp. 1177-1204.

Simanjorang, R. D. Ekonomika, F. Kristen, U. dan Wacana, S. 2016. Praktik Perlakuan Akuntansi Aset Biologis pada Perusahaan Perkebunan (Persero) di Indonesia. Jurnal Akuntansi. Vol.3 No.2. 